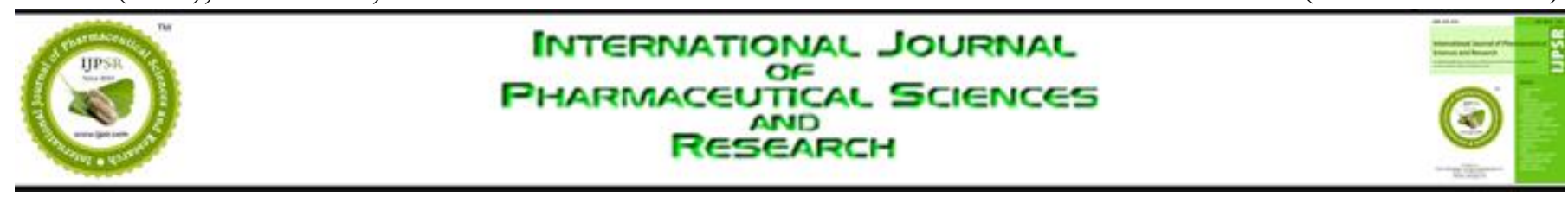

Received on 19 November 2019; received in revised form, 25 February 2020; accepted, 13 March 2020; published 01 November 2020

\title{
SIMULTANEOUS ESTIMATION OF VELPATASVIR AND SOFOSBUVIR IN BULK AND COMBINED TABLET DOSAGE FORM BY A SIMPLE VALIDATED STABILITY INDICATING RP-HPLC METHOD
}

Ramreddy Godela * and G. Sowjanya

GITAM Institute of Pharmacy, GITAM Deemed to be University, Visakhapatnam - 530045, Andhra Pradesh, India.

Keywords:

Velpatasvir, Sofosbuvir, Sensitive, Isocratic elution, Stability indicating method

Correspondence to Author:

Ramreddy Godela

Research Scholar, GITAM Institute of Pharmacy, GITAM Deemed to be University, Visakhapatnam - 530045, Andhra Pradesh, India.

E-mail: ramreddy.godela@gmail.com

\begin{abstract}
A Simple, sensitive, specific and stability indicating RPHPLC method was developed for the simultaneous estimation of velpatasvir and sofosbuvir in bulk and tablet dosage form. Effective separation attained by injecting $10 \mu \mathrm{L}$ of the standard solution containing velpatasvir and sofosbuvir into Xbrdige Phenyl $(250 \times 4.6 \mathrm{~mm}, 5 \mu, 100$ $\left.\mathrm{A}^{0}\right)$ column, with a mobile phase containing methanol, buffer $(0.1 \%$ formic acid in water) and acetonitrile in 40:30:30 v/v ratio, at a flow rate of $1 \mathrm{ml} / \mathrm{min}$. The eluted analytes were effectively responded qualitatively and quantitatively at $273 \mathrm{~nm}$ wavelength. The drugs were experienced in stress conditions such as oxidative, acid, base, photolytic, and thermal degradation. The retention times of sofosbuvir and velpatasvir were observed at 3.4 and $5.1 \mathrm{~min}$, respectively. The method has a good linear response in the concentration range of $10-30 \mu \mathrm{g} / \mathrm{ml}$ and $40-120 \mu \mathrm{g} / \mathrm{ml}$ for velpatasvir and sofosbuvir respectively. LOD and LOQ were calculated as $1 \mu \mathrm{g} / \mathrm{ml}$ and $4 \mu \mathrm{g} / \mathrm{ml}$ for velpatasvir, $4 \mu \mathrm{g} / \mathrm{ml}$, and $13 \mu \mathrm{g} / \mathrm{ml}$ for sofosbuvir. All the obtained validation parameters have been satisfied the acceptance limits of ICH guidelines. The degradants peaks were resolved significantly from sofosbuvir and velpatasvir peaks. The developed method was sensitive, specific, accurate, and stability-indicating. Thus, this method can be useful in the quality control department to estimate velpatasvir and sofosbuvir perfectly.
\end{abstract}

INTRODUCTION: Hepatitis $\mathrm{C}$ virus (HCV) infection is caused by a single standard RNA virus that can replicate in the liver causes cirrhosis and hepatocellular carcinoma ${ }^{1}$. The combination of velpatasvir and sofosbuvir termed as direct-acting antivirals (DAAs) can be used to treat $\mathrm{HCV}$ patients safely and successfully ${ }^{1}$.

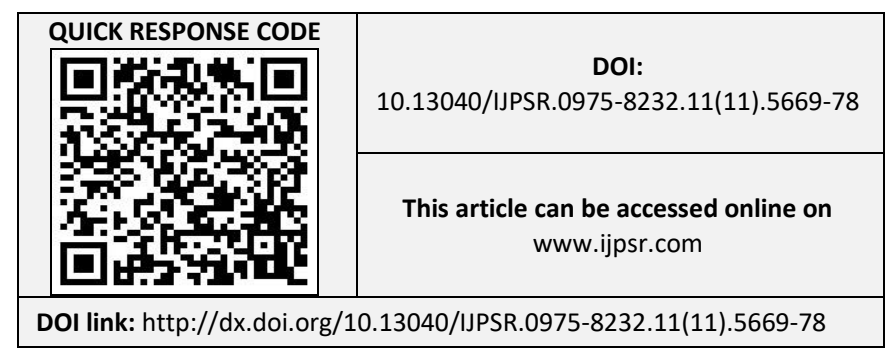

Chemically, sofosbuvir is propan-2-yl (2S)-2- $\{[(\mathrm{S})-$ $\{[(2 \mathrm{R}, 3 \mathrm{R}, 4 \mathrm{R}, 5 \mathrm{R})-$ 5- (2,4-dioxo-1,2,3,4-tetrahydro pyrimidin-1-yl)- 4- fluoro-3-hydroxy-4-methyloxolan-2yl] methoxy\} (phenoxy) phosphoryl] amino propanoate with molecular formula $\mathrm{C}_{22} \mathrm{H}_{29} \mathrm{FN}_{3} \mathrm{O}_{9} \mathrm{P}$ ${ }^{2}$. Sofosbuvir is a prodrug metabolized into its active form 2'- deoxy- 2'- $\alpha$ - fluoro- $\beta$ - C-methyluridine-5'-triphosphate.

Sofosbuvir competitively blocks the nonstructural protein 5B (NS5B) polymerase, therefore, inhibiting the chain termination reaction in the HCV-RNA synthesis 3, 4 . Chemically, velpatasvir is Methyl $\{(2 s)-1-[(2 s, 5 s)-2-2-(9-\{2[(2 s, 4 s)-1-\{(2 R)-2-2$ [methoxycarbonyl) amino]- 2- phenylacetyl $\}$ - 4- 
(methoxymethyl)- 2- pyrrolidinyl]- 1H- imidazol-4yl \}-1,11-dihydroisochromeno[4,3:6,7]naptho[1,2d] imidazol-2-yl)- 5- mthyl-1-pyrrolydinyl]-3-methyl1-oxo-2-butanyl \} carbamate with molecular formula $\mathrm{C}_{49} \mathrm{H}_{54} \mathrm{~N}_{8} \mathrm{O}_{8}{ }^{5}$. It inhibits the Nonstructural protein 5A (NS5A), which involves in HCV-RNA replication. Chemical structures of velpatasvir and sofosbuvir were shown in Fig. 1.

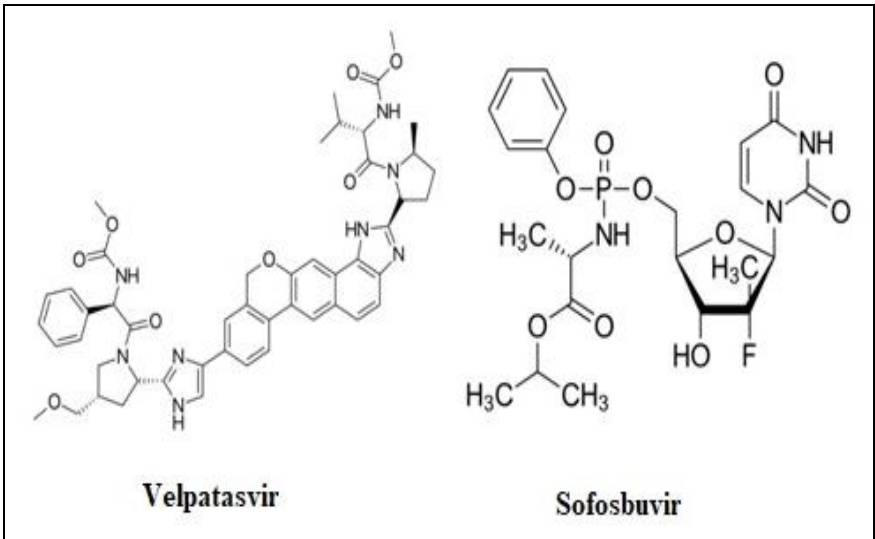

FIG. 1: CHEMICAL STRUCTURES OF VELPATASVIR AND SOFOSBUVIR

The requirement of an effective, simple, and economical analytical method in the pharmaceutical industry is essential to analyze the drugs individually or simultaneously in combination with other drugs. RP-HPLC method is one of the prominent analytical methods to determine the API in bulk and formulation qualitatively and quantitatively with accuracy and precision. Ample literature review of velpatasvir and sofosbuvir unveiled that different analytical methods such as UV and RP-HPLC methods were available for estimation of velpatasvir and sofosbuvir individually ${ }^{6,7,8}$. In addition to those there are few RP-HPLC methods were reported for measurement of velpatasvir, sofosbuvir and voxilaprevir simultaneously in bulk and combined dosage form ${ }^{9}$. Only few UV and RP-HPLC methods were reported for estimation of velpatasvir and sofosbuvir ${ }^{10,11,12,13}$. Till date a single method was not reported with good sensitive, economical and stability indicating RP-HPLC method in literature for the estimation of velpatasvir and sofosbuvir simultaneously in bulk and tablet dosage form. Hence, we have undertaken current research work to develop an effective, sensitive, economical and stability indicating RP-HPLC method for analysis of velpatasvir and sofosbuvir in the drug substance and tablet dosage form. The developed method was validated as per the Q2 specification of ICH guidelines, and forced degradation conditions in stability studies were maintained as per Q1A specification of $\mathrm{ICH}$ recommendations.

\section{MATERIALS AND METHODS: Active} pharmaceutical ingredients of velpatasvir and sofosbuvir were provided by hetero drugs private limited, Hyderabad as gift sample. HPLC grade methanol, acetonitrile, and water were procured from Finar chemicals, Ahmedabad, India.

Chromatographic Conditions: RP-HPLC method was done on WATERS 2695 with PDA detector and auto sampling system; data-processing and data computation were assessed by Empower 2 software. Effective separation attained by injecting $10 \mu \mathrm{L}$ of the standard solution containing velpatasvir and sofosbuvir into Xbrdige Phenyl $(250 \times 4.6$ $\mathrm{mm}, 5 \mu, 100 \mathrm{~A}^{0}$ ) column, with a mobile phase containing methanol, buffer $(0.1 \%$ formic acid in water) and acetonitrile in 40:30:30 v/v ratio, at a flow rate of $1 \mathrm{ml} / \mathrm{min}$. The eluted analytes were effectively responded qualitatively and quantitatively at $273 \mathrm{~nm}$ wavelength. Ambient temperature was maintained in the injection port and in the analytical column. The $0.45 \mu \mathrm{m}$ nylon filters were used to filter all the solutions before introducing them into HPLC system.

Preparation of Standard Solution: $20 \mathrm{mg}$ of velpatasvir and $80 \mathrm{mg}$ of sofosbuvir pure bulk powders were weighed and transferred into $100 \mathrm{ml}$ volumetric flask, diluted to $100 \mathrm{ml}$ with diluent (acetonitrile and water (50:50)). The resultant solution was further diluted with the same diluent to obtain a solution containing $20 \mu \mathrm{g} / \mathrm{ml}$ and 80 $\mu \mathrm{g} / \mathrm{ml}$ concentration of velpatasvir and sofosbuvir, respectively, which is considered as $100 \%$ level concentration.

Preparation of Sample Solution: The tablet (VELASOF) powder equivalent to $20 \mathrm{mg}$ velpatasvir of and $80 \mathrm{mg}$ of sofosbuvir was transferred into $100 \mathrm{ml}$ volumetric flask, diluted to $100 \mathrm{ml}$ with diluents. The resultant solution was further diluted with the same diluent to obtain a solution containing $20 \mu \mathrm{g} / \mathrm{ml}$ and $80 \mu \mathrm{g} / \mathrm{ml}$ concentration of velpatasvir and sofosbuvir, respectively. The sample solution was filtered through the $0.25 \mu \mathrm{m}$ Nylon filter. 
Method Validation: The developed method was validated as per Q2 specifications of $\mathrm{ICH}$ guidelines

System Suitability Test: System suitability test was accomplished by injecting a standard solution of velpatasvir and sofosbuvir in 5 replicates. System suitability parameters like theoretical plate count $(\mathrm{N})$, tailing factor $(\mathrm{T})$ and percentage relative standard deviation (\%RSD) values were computed.

Linearity: The linearity of an analytical method represents that the obtained test outcomes are directly proportional to test concentrations. The linearity of the present method was done by injecting the concentrations ranges from $10 \mu \mathrm{g} / \mathrm{ml}$ to $30 \mu \mathrm{g} / \mathrm{ml}$ of velpatasvir and $40 \mu \mathrm{g} / \mathrm{m}$ to 120 $\mu \mathrm{g} / \mathrm{ml}$ of sofosbuvir into HPLC system with optimized chromatographic conditions. The calibration curve was plotted for both drugs over concentration $v s$. peak area, and the regression coefficient $\left(\mathrm{r}^{2}\right)$ value was reckoned.

Precision: The closeness agreement among observed results of multiple sampling of homogenous analyte referred to as precision. Generally, it has to do on the same day (Intraday or repeatability) and in three different days (inter-day or reproducibility). The repeatability and reproducibility of the current method were performed by injecting standard solution for 5 times in a day and 3 times per day for three continuous days, \% RSD was reckoned for peak areas thus obtained.

Accuracy: The accuracy of the method was accomplished by recovery studies in which the known amount of sample solution spiked at three different standard concentration levels about 50, 100 , and $150 \%$, each level of solution injected in triplicate. The mean percentage recovery at three different levels of the drug solution was calculated.

Specificity: The ability of the method to assess the intended analyte qualitatively and quantitatively in the presence of other substances like impurities and placebo without interferences said as the specificity of the method. It can be performed by sequence injecting a volume of $10 \mu \mathrm{L}$ blank solution, standard solution, and standard solution with placebo in sequence manner. The retention time (RT) of analytes in the chromatogram of the standard solution alone and standard solution with placebo was observed and interference of any other peak with the peaks of velpatasvir and sofosbuvir in the obtained chromatograms.

Sensitivity: Standard deviation method used to calculate the LOD and LOQ by using the following formulae.

$$
\begin{gathered}
\mathrm{LOD}=3 \sigma / \mathrm{S} \\
\mathrm{LOQ}=10 \sigma / \mathrm{S}
\end{gathered}
$$

Where $\sigma$ is the standard deviation of the peak areas, $S$ is the slope of the linearity curve

Robustness: The robustness of the method was checked by slight changes that have been made to the flow rate, and wavelength of maximum absorption. It was performed and confirmed by evaluating the system suitability parameters such as theoretical plates $(\mathrm{N})$, tailing factor $(\mathrm{T})$ after changing the flow rate of mobile phase $( \pm 0.1$ $\mathrm{ml} / \mathrm{min}$ ), and wavelength of maximum absorption $( \pm 2 \mathrm{~nm})$.

Forced Degradation Studies: In the forced degradation studies, intentionally drug substance is exposed to stress conditions more intense than accelerated conditions. Forced degradation studies help to determine the chemical stability of the drug molecule. These studies were highly considered in the development of stable formulation. As per ICH Q1A, QIB, and Q2B guidelines, the forced degradation studies were performed ${ }^{14}$.

Acid Hydrolysis: $10 \mathrm{ml}$ of standard stock solution mixed with $2 \mathrm{ml}$ of $0.1 \mathrm{~N} \mathrm{HCl}$ and reflux on the heating mantle at $70{ }^{\circ} \mathrm{C}$ for $2 \mathrm{~h}$, kept the above solution in temperature controlling unit for 1 day at $70{ }^{\circ} \mathrm{C}$ temperature, cool and neutralize resultant solution with $0.1 \mathrm{~N} \mathrm{NaOH}$ and further diluted with diluent to obtain a solution containing $20 \mu \mathrm{g} / \mathrm{ml}$ and $80 \mu \mathrm{g} / \mathrm{ml}$ concentration of velpatasvir and sofosbuvir respectively.

Base Hydrolysis: $10 \mathrm{ml}$ of standard stock solution mixed with $2 \mathrm{ml}$ of $0.1 \mathrm{~N} \mathrm{NaOH}$ and reflux on the heating mantle at $70{ }^{\circ} \mathrm{C}$ for $2 \mathrm{~h}$, kept the above solution in temperature controlling unit for 1 day at $70{ }^{\circ} \mathrm{C}$ temperature, cool and neutralize resultant solution with $0.1 \mathrm{~N} \mathrm{HCl}$ and further diluted with diluent to obtain a solution containing $20 \mu \mathrm{g} / \mathrm{ml}$ and $80 \mu \mathrm{g} / \mathrm{ml}$ concentration of velpatasvir and sofosbuvir respectively. 
Oxidative Degradation: $10 \mathrm{ml}$ of standard stock solution mixed with $2 \mathrm{ml}$ of $3 \%$ hydrogen peroxide and reflux on the heating mantle at $70{ }^{\circ} \mathrm{C}$ for $2 \mathrm{~h}$, kept the above solution in temperature controlling unit for 1 day at $70{ }^{\circ} \mathrm{C}$ temperature, the resultant solution further diluted with diluent to obtain a solution containing $20 \mu \mathrm{g} / \mathrm{ml}$ and $80 \mu \mathrm{g} / \mathrm{ml}$ concentration of velpatasvir and sofosbuvir respectively.

Thermal Degradation: $10 \mathrm{ml}$ of standard stock solution was placed in the heating chamber at 80 ${ }^{\circ} \mathrm{C} / 75 \% \mathrm{RH}$ for 1 day. The resultant solution further diluted with diluent to obtain a solution containing $20 \mu \mathrm{g} / \mathrm{ml}$ and $80 \mu \mathrm{g} / \mathrm{ml}$ concentration of velpatasvir and sofosbuvir, respectively.

Photodegradation: $10 \mathrm{ml}$ of standard stock solution was exposed to UV light in the UV chamber for a 1-day resultant solution further diluted with diluent to obtain a solution containing $20 \mu \mathrm{g} / \mathrm{ml}$ and $80 \mu \mathrm{g} / \mathrm{ml}$ concentration of velpatasvir and sofosbuvir respectively.

Assay: The assay was done by injecting standard solution and sample solution having a concentration of about $20 \mu \mathrm{g} / \mathrm{ml}$ and $80 \mu \mathrm{g} / \mathrm{ml}$ of velpatasvir and sofosbuvir, respectively. The percentage of purity was estimated by using a method described elsewhere ${ }^{15}$.

RESULTS AND DISCUSSION: The first step in the analytical method is the selection of mobile phase and diluents, which depend upon the solubility of the drug in different solvents. Hence, the solubility of both drugs was checked in different solvents and came to a conclusion that sofosbuvir was slightly soluble in acetonitrile $(\mathrm{ACN})$ and methanol, freely soluble in water and velpatasvir was freely soluble in water and methanol. Based on the solubility studies, ACN and water in (50:50) ratio selected as diluents to make the standard and sample solutions.

Method Optimization: The optimized method was selected by performing trial and error method, in which different mobile phase compositions with different ratios, different types of columns and variation in the flow rate were used to get chromatogram with acceptable system suitability parameter values. Finally, the method using Xbrdige Phenyl $\left(250 \times 4.6 \mathrm{~mm}, 5 \mu, 100 \mathrm{~A}^{0}\right)$ column, with a mobile phase containing methanol, buffer $(0.1 \%$ formic acid in water) and acetonitrile in 40:30:30 v/v ratio, at a flow rate of $1 \mathrm{ml} / \mathrm{min}$ was confirmed as the optimized method. The trial and error method results were stated in Table 1, trial 4 chosen as optimized chromatographic conditions elutes the sofosbuvir and velpatasvir at $3.4 \mathrm{~min}$ and $5.1 \mathrm{~min}$, respectively, and the obtained chromatogram of the optimized method shown in Fig. 2.

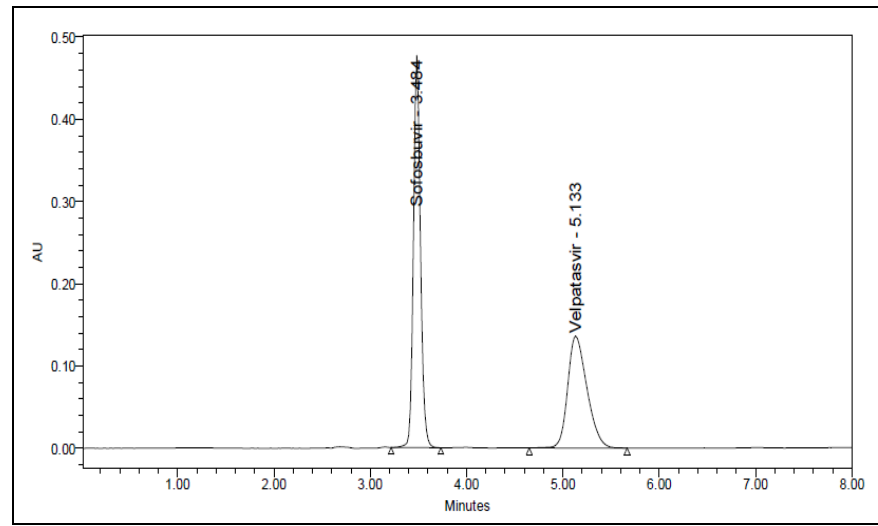

FIG. 2: OPTIMIZED CHROMATOGRAM OF THE METHOD

\section{Method Validation:}

System Suitability: The parameters such as \% RSD, USP tailing factor, and USP plate count values showed in Table 2 have not deviated from the acceptance limits Table 3 of ICH Q2 specifications.

TABLE 1: DIFFERENT TRIALS

\begin{tabular}{|c|c|c|c|c|c|}
\hline Trail & Column & Buffer & Mobile Phase & Flow rate $\mathrm{ml} / \mathrm{min}$ & Observation \\
\hline 1 & $\begin{array}{c}\text { Intersil ODS } \\
(150 \times 4.6 \mathrm{~mm}, 5 \mu \mathrm{m})\end{array}$ & $\begin{array}{l}0.1 \% \text { Formic } \\
\text { acid in Water }\end{array}$ & $\begin{array}{c}\text { Buffer: ACN : } \\
\text { Methanol }(40: 60)\end{array}$ & 1 & Only sofosbuvir peak eluted \\
\hline 2 & $\begin{array}{l}\text { Intersil ODS }(150 \times \\
4.6 \mathrm{~mm}, 5 \mu \mathrm{m})\end{array}$ & $\begin{array}{l}0.1 \% \text { Formic } \\
\text { acid in Water }\end{array}$ & $\begin{array}{c}\text { Buffer: ACN : } \\
\text { Methanol }(35: 15: 50)\end{array}$ & 1 & $\begin{array}{c}\text { Broad velpatasvir peak was } \\
\text { very Broad }\end{array}$ \\
\hline 3 & $\begin{array}{c}\text { Intersil ODS } \\
(150 \times 4.6 \mathrm{~mm}, 5 \mu \mathrm{m})\end{array}$ & $\begin{array}{l}0.1 \% \text { Formic } \\
\text { acid in Water }\end{array}$ & $\begin{array}{c}\text { Buffer: ACN : } \\
\text { Methanol }(40: 25: 35)\end{array}$ & 1 & $\begin{array}{l}\text { Very low resolution between } \\
\text { peaks seems as one peak }\end{array}$ \\
\hline 4 & $\begin{array}{c}\text { Phenyl XDB } \\
(250 \times 4.6 \mathrm{~mm}, 5 \mu \mathrm{m})\end{array}$ & $\begin{array}{l}0.1 \% \text { Formic } \\
\text { acid in Water }\end{array}$ & $\begin{array}{c}\text { Buffer: ACN : } \\
\text { Methanol }(30: 30: 40)\end{array}$ & 1 & $\begin{array}{c}\text { The resolution between peaks } \\
\text { and the efficiency of the } \\
\text { peaks was good }\end{array}$ \\
\hline
\end{tabular}


TABLE 2: RESULTS OF SYSTEM SUITABILITY TEST FOR SOFOSBUVIR AND VELPATASVIR

\begin{tabular}{ccccccccc}
\hline & \multicolumn{4}{c}{ Sofosbuvir } & \multicolumn{4}{c}{ Velpatasvir } \\
\hline Injection & RT & $\begin{array}{c}\text { Peak } \\
\text { area }\end{array}$ & $\begin{array}{c}\text { USP } \\
\text { Plate count }\end{array}$ & $\begin{array}{c}\text { USP } \\
\text { tailing }\end{array}$ & RT & $\begin{array}{c}\text { Peak } \\
\text { area }\end{array}$ & $\begin{array}{c}\text { USP plate } \\
\text { count }\end{array}$ & $\begin{array}{c}\text { USP } \\
\text { tailing }\end{array}$ \\
\hline 1 & 3.484 & 2404024 & 10672 & 1.12 & 5.133 & 1889947 & 3095 & 1.28 \\
2 & 3.49 & 2452816 & 11266 & 1.14 & 5.232 & 1900427 & 3264 & 1.3 \\
3 & 3.415 & 2429435 & 10733 & 1.12 & 5.111 & 1893444 & 3088 & 1.29 \\
4 & 3.484 & 2328815 & 12791 & 1.12 & 5.245 & 1819389 & 3216 & 1.3 \\
5 & 3.483 & 2383147 & 11245 & 1.15 & 5.254 & 1825555 & 3251 & 1.29 \\
6 & 3.484 & 2404024 & 10672 & 1.12 & 5.133 & 1889947 & 3095 & 1.28 \\
MEAN & & 2400377 & & & & 1869785 & & \\
SD & 42517.78 & & & & 36899.17 & & \\
\%RSD & & & & & & & & \\
\hline
\end{tabular}

Linearity: The regression coefficient $\left(r^{2}\right)$ values for the concentration range from 40 to $120 \mu \mathrm{g} / \mathrm{ml}$ of sofosbuvir and 10 to $30 \mu \mathrm{g} / \mathrm{ml}$ of velpatasvir were 0.998 and 0.998 for sofosbuvir, and velpatasvir respectively states that the method has good linearity for the given concentration ranges. The results of the linearity mentioned in Table 4 and Fig. 3 .
TABLE 3: ACCEPTANCE LIMITS OF SYSTEM SUITABILITY PARAMETERS

\begin{tabular}{cc}
\hline Parameter & Acceptance limit \\
\hline USP & $>2000$ \\
Plate count & $\leq 2$ \\
USP & $\leq 2$ \\
tailing & $>2$ \\
\%RDD & \\
Resolution & \\
\hline
\end{tabular}

TABLE 4: LINEARITY CURVE OF SOFOSBUVIR AND VELPATASVIR

\begin{tabular}{cccccc}
\hline S. no. & \multirow{2}{*}{ level } & \multicolumn{2}{c}{ Velpatasvir } & Sofosbuvir \\
\cline { 3 - 6 } & & Concentration $(\boldsymbol{\mu g} / \mathbf{m l})$ & Peak area & Concentration $(\boldsymbol{\mu g} / \mathbf{m l})$ & Peak area \\
\hline 1 & 50 & 10.0 & 952220 & 40 & 1135443 \\
2 & 75 & 15.0 & 1457282 & 60 & 1817470 \\
3 & 100 & 20.0 & 1889947 & 80 & 2404024 \\
4 & 125 & 25.0 & 2344309 & 100 & 2957034 \\
5 & 150 & 30.0 & 2888340 & 120 & 3575122 \\
& Correlation coefficient $\left(\mathrm{r}^{2}\right)$ & 0.998 & & 0.998 \\
\hline
\end{tabular}
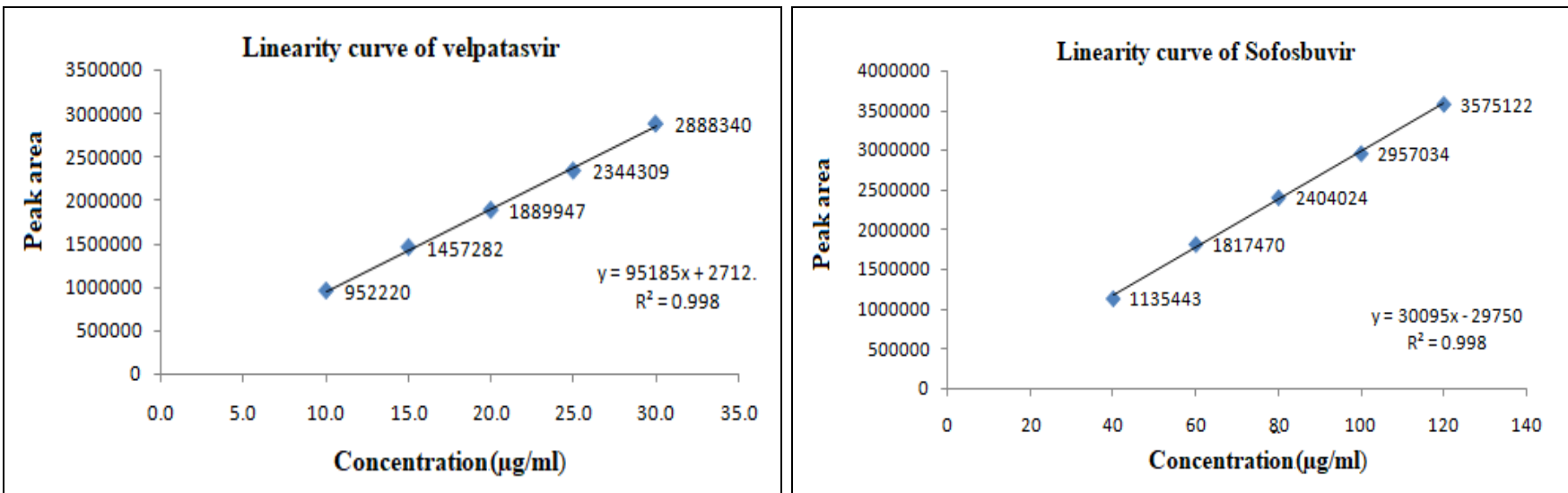

FIG. 3: CALIBRATION CURVE OF VELPATASVIR AND SOFOSBUVIR

Accuracy: The Percentage mean recovery at three velpatasvir with in the $\mathrm{ICH}$ acceptance limits different levels of concentration for sofosbuvir and $(100 \% \pm 2)$ were shown in Table 5.

TABLE 5: RESULTS OF PERCENTAGE RECOVERY

\begin{tabular}{ccccc}
\hline Drug name & \% Level & Amount added $(\boldsymbol{\mu g} / \mathbf{m l})$ & Amount recovered $(\boldsymbol{\mu g} / \mathbf{m l})$ & \% recovery \\
\hline Velpatasvir & 50 & 10 & 9.89 & 98.9 \\
& & 10 & 9.84 & 98.4 \\
& 10 & 20 & 9.93 & 99.3 \\
& \multirow{2}{*}{100} & 20 & 19.78 & 98.9 \\
& & & 19.68 & 98.4 \\
\hline
\end{tabular}




\begin{tabular}{ccccc}
\hline & & 20 & 19.86 & 99.3 \\
& 150 & 30 & 30 & 100 \\
Sofosbuvir & 30 & 29.46 & 98.2 \\
& & 30 & 30.09 & 100.3 \\
& 50 & 40 & 40 & 100 \\
& & 40 & 39.92 & 99.8 \\
& 400 & 80 & 40 & 100 \\
& & 80 & 79.04 & 98.8 \\
& 80 & 79.92 & 99.9 \\
& 150 & 120 & 78.64 & 98.3 \\
& 120 & 118.56 & 98.8 \\
& 120 & 118.08 & 98.4 \\
\hline
\end{tabular}

Precision: The \% RSD of the injected standard solution of velpatasvir and sofosbuvir was $\leq 2$, and results were mentioned in Table 6 depicts the method with good precision.
Sensitivity: The LOD and LOQ of the velpetasvir were $1 \mu \mathrm{g} / \mathrm{ml}$ and $4 \mu \mathrm{g} / \mathrm{ml}$, and sofosbuvir was 4 $\mu \mathrm{g} / \mathrm{ml}$, and $13 \mu \mathrm{g} / \mathrm{ml}$ represents good sensitivity of the method.

TABLE 6: RESULTS OF INTRADAY AND INTER-DAY PRECISION OF 100\% LEVEL SOLUTION

\begin{tabular}{|c|c|c|c|c|c|}
\hline \multirow{2}{*}{$\frac{\text { Precision }}{\text { Intra day }}$} & \multirow[b]{2}{*}{ Sample name } & \multicolumn{2}{|c|}{ Velpatasvir $(20 \mu \mathrm{g} / \mathrm{ml})$} & \multicolumn{2}{|c|}{ Sofosbuvir $(80 \mu \mathrm{g} / \mathrm{ml})$} \\
\hline & & RT & Peak area & RT & Peak area \\
\hline & Injection 1 & 5.264 & 1994422 & 3.5 & 2434193 \\
\hline & injection 2 & 5.106 & 1997574 & 3.403 & 2429614 \\
\hline & injection 3 & 5.106 & 1999319 & 3.403 & 2429614 \\
\hline & injection 4 & 5.232 & 2020427 & 3.49 & 2452816 \\
\hline & injection 5 & 5.111 & 2003444 & 3.415 & 2429435 \\
\hline & MEAN & 5.164 & 10015186 & 3.442 & 2435134.4 \\
\hline & SD & 0.07772 & 10252.608 & 0.04858 & 10086.6 \\
\hline & $\%$ RSD & 1.50507 & 0.1023706 & 1.41121 & 0.4142112 \\
\hline Inter Day & Sample name & RT & Peak area & RT & Peak area \\
\hline \multirow{3}{*}{ day-1 } & Injection 1 & 5.257 & 1808711 & 3.49 & 2290604 \\
\hline & Injection 2 & 5.254 & 1841158 & 3.487 & 2293687 \\
\hline & Injection 3 & 5.26 & 1819389 & 3.486 & 2265940 \\
\hline \multirow[t]{3}{*}{ day-2 } & Injection 1 & 5.312 & 1828679 & 3.506 & 2307972 \\
\hline & Injection 2 & 5.245 & 1819389 & 3.484 & 2328815 \\
\hline & Injection 3 & 5.254 & 1825555 & 3.483 & 2283147 \\
\hline \multirow[t]{6}{*}{ day-2 } & Injection 1 & 5.264 & 1904422 & 3.5 & 2434193 \\
\hline & injection 2 & 5.106 & 1817574 & 3.403 & 2429614 \\
\hline & injection 3 & 5.106 & 1899319 & 3.403 & 2429614 \\
\hline & MEAN & 5.22 & 1840466.2 & 3.471 & 2340398.44 \\
\hline & SD & 0.072 & 35945.61 & 0.04 & 70165.1 \\
\hline & $\%$ RSD & 1.37 & 1.95 & 1.14 & 1.134 \\
\hline
\end{tabular}

Robustness: Deliberately small variations in flow rate and detection wavelength or absorption maximum of the method consistently produced values of system suitability parameter in the acceptable range Table 7 was the strong evidence for the robustness of the method.

TABLE 7: RESULTS OF THE ROBUSTNESS OF 100\% LEVEL SOLUTION

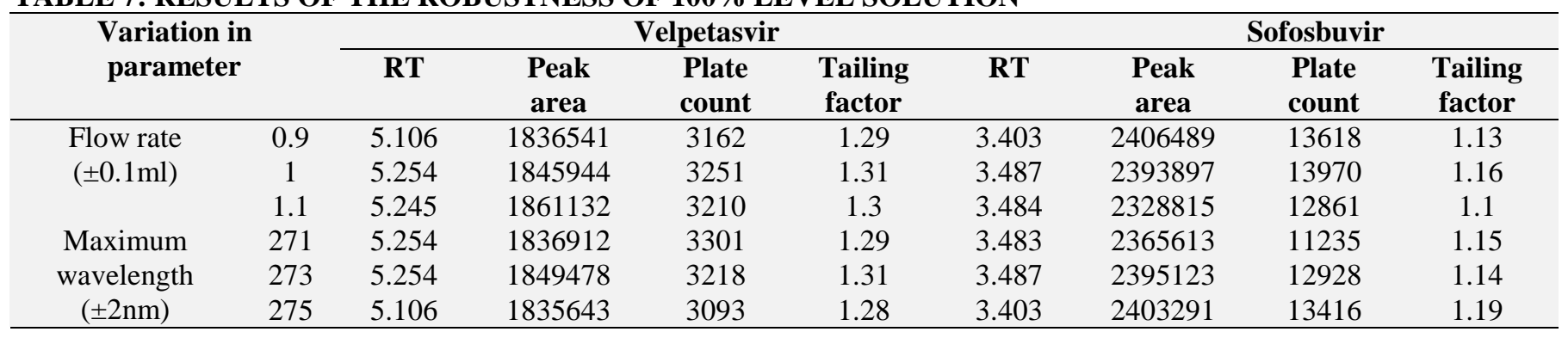


Forced Degradation: The forced degradation conditions mentioned in the method was appropriate to cause the degradation of the sofosbuvir and velpatasvir. At mentioned thermal photolytic stress condition, percentage degradation was very negligible, consider as drug substance was stable at these conditions. The results were shown in Table 8 and Fig. 4.
TABLE 8: RESULTS OF FORCED DEGRADATION STUDIES

\begin{tabular}{ccc}
\hline Stress conditions & \multicolumn{2}{c}{ \% Degradation } \\
\cline { 2 - 3 } & Vepatasvir & Sofosbuvir \\
\hline Acidic/0.1N HCl/reflux at $70{ }^{\circ} \mathrm{C} / 24 \mathrm{~h}$ & 13.6 & 22.0 \\
Basic $/ 0.1 \mathrm{~N} \mathrm{NaOH} /$ & 12.7 & 18.4 \\
reflux at $70^{\circ} \mathrm{C} / 24 \mathrm{~h}$ & & \\
Oxidation $/ 3 \% \mathrm{H}_{2} \mathrm{O}_{2} / 70^{\circ} \mathrm{C} / 24 \mathrm{~h}$ & 12.7 & 19.5 \\
Thermal $/ 80^{\circ} \mathrm{C} / 75 \% \mathrm{RH}$ for $24 \mathrm{~h}$ & 4.2 & 0.85 \\
Photolytic/UV light $/ 24 \mathrm{~h}$ & 0.21 & 0.45 \\
\hline
\end{tabular}
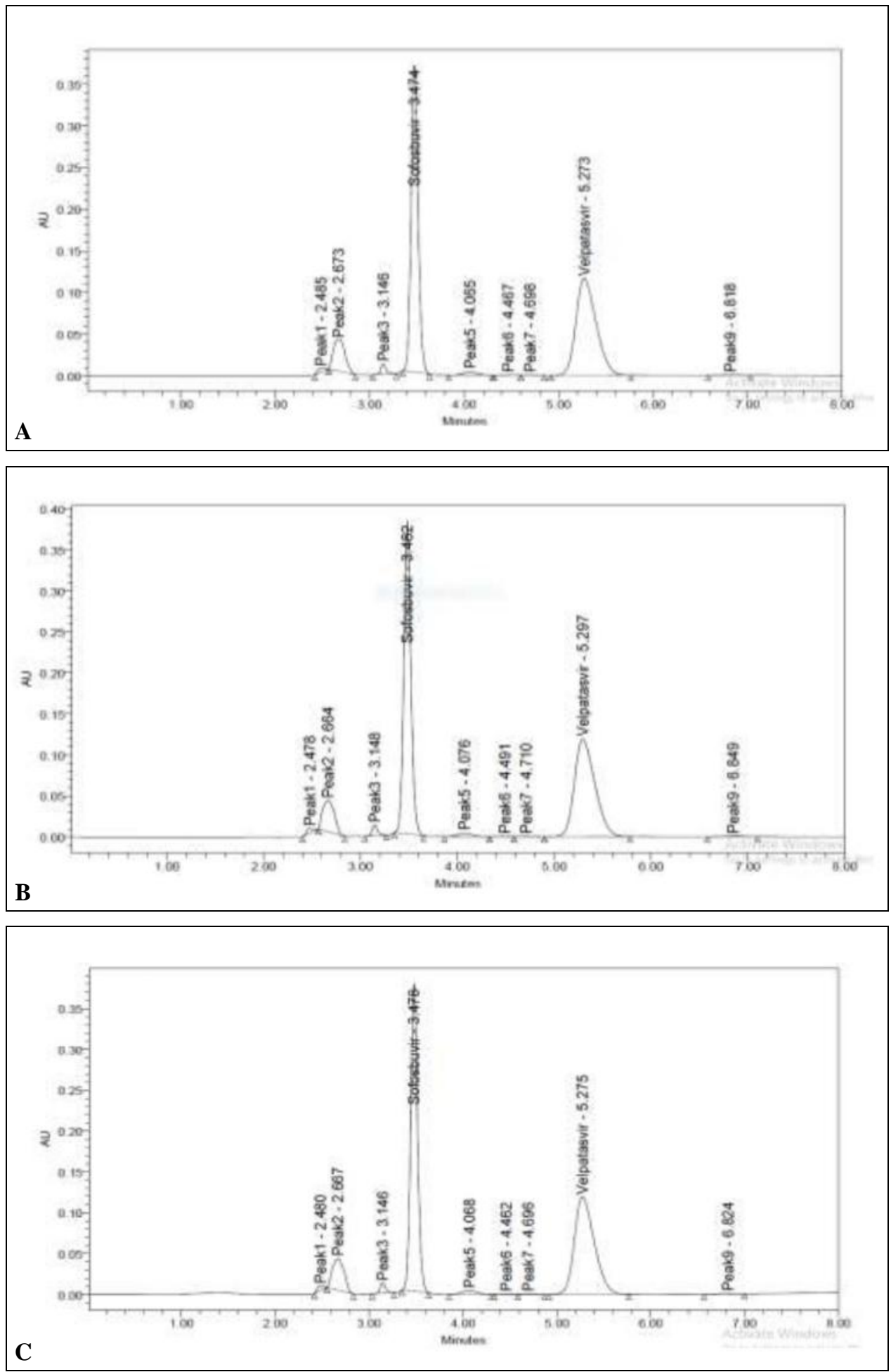

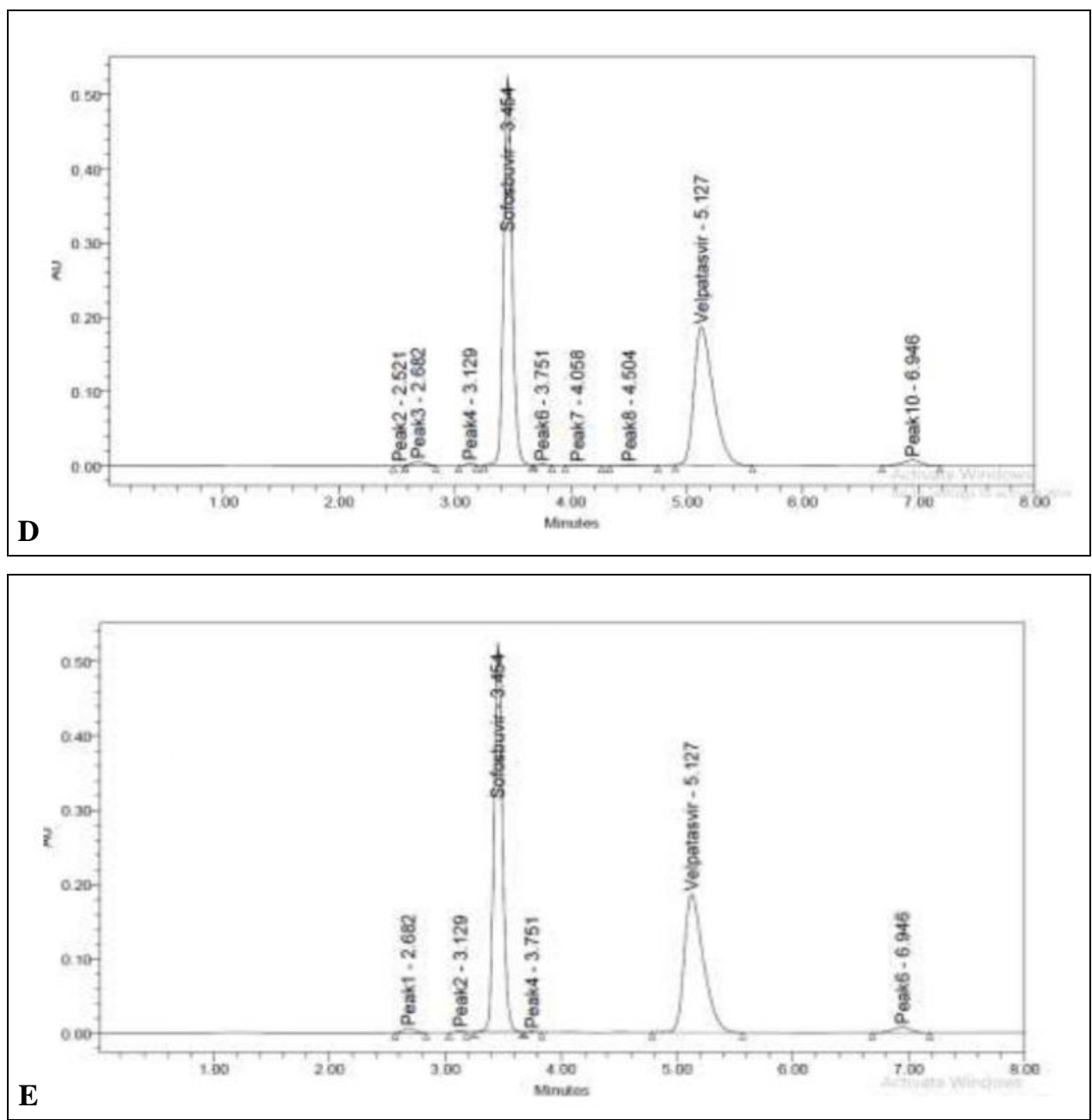

FIG. 4: CHROMATOGRAM OF BASE DEGRADATION. CHROMATOGRAMS A TO E- A. ACID HYDROLYSIS, B. BASIC HYDROLYSIS, C. PEROXIDE OXIDATION, D. THERMAL DEGRADATION, E. PHOTOLYTIC DEGRADATION

Assay: Percentage purity of the sofosbuvir and in the range of $98 \%$ to $102 \%$. The results were velpatasvir in commercially available tablets were shown in Table 9 and Fig. 5.

TABLE 9: RESULTS OF \% ASSAY OF THE TABLET DOSAGE FORM

\begin{tabular}{ccccccc}
\hline Drug & Peak name & Retention time & Peak Area & USP Tailing & USP Plate count & \%Assay \\
\hline Velpatasvir & Standard & 3.48 & 1885479 & 1.29 & 3058 & $98.2 \%$ \\
& Test & 3.49 & 1852184 & 1.31 & 3201 & 14201 \\
Sofosbuvir & Standard & 5.13 & 2415221 & 1.12 & 13961 \\
& Test & 5.25 & 2386340 & 1.15 & $>2$ & $>2000$ \\
\hline
\end{tabular}

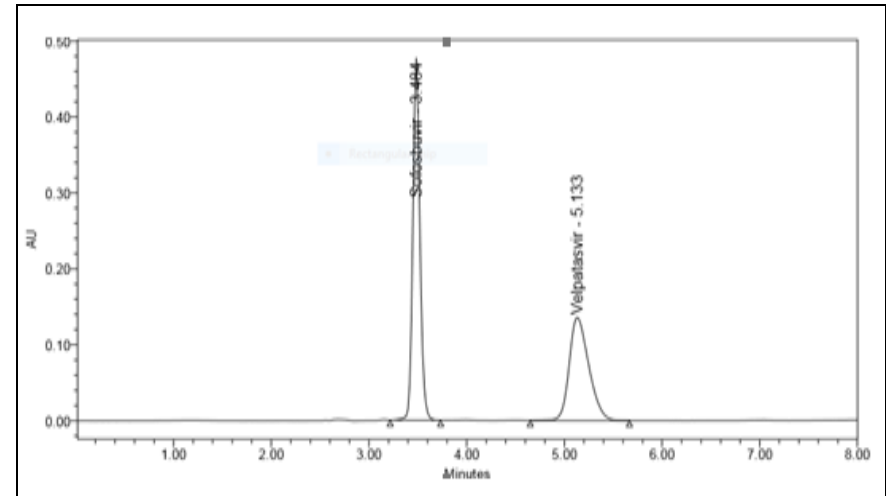

STANDARD SOLUTION CHROMATOGRAM

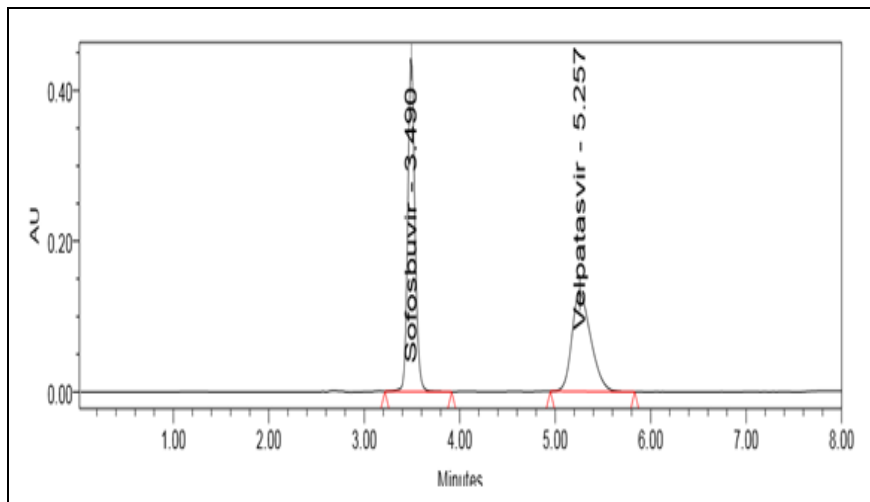

SAMPLE SOLUTION CHROMATOGRAM

International Journal of Pharmaceutical Sciences and Research 
In general, stability indicating RP-HPLC method has a significant role in both qualitative and quantitative determination of the drugs. As of now, no single stability-indicating RP-HPLC method with good sensitivity and retention time was not developed. In reported methods, sensitivity and linear concentration range were too high. And also, the resolution between drug peak and degradants was very low. Hence attempts were done to develop an effective, sensitive stability-indicating RP-HPLC method. The retention time in the currently developed method was $5.1 \mathrm{~min}$ for velpatasvir, and $3.4 \mathrm{~min}$ for sofosbuvir depicts the method with good retention time, which can be said as an economical method. The computed and statistical results of the validation parameters of the analytical method were within the acceptance limits ICH guidelines.

CONCLUSION: An effective, sensitive, simple and specific RP-HPLC method with isocratic elution was developed to estimate velpatasvir and sofosbuvir simultaneously in bulk and its tablet dosage form. Different stress conditions have been applied to the drug solution to assess the stabilityindicating property of the method. The proposed method was successfully separate velpatasvir, sofosbuvir, and degradants with good resolution and quantified the active contents at minute concentration levels. Hence, the proposed method is expected as a revival to regular analysis of combined dosage in the pharmaceutical industry.

AUTHORS CONTRIBUTION: Both the authors contributed equally in the design of the work, acquisition, and interpretation of data, and manuscript preparation; all authors have read and approved the manuscript.

FUNDING: It is self-financed, no funding was obtained from any organization and research funding bodies.

ACKNOWLEDGEMENT: The authors are thankful to Fortune Pharma, Hyderabad for providing lab facilities. The authors are also thankful to Department of pharmaceutical Analysis, GITAM University, Vishakhapatnam, India for encouragement. The authors are very thankful to Dr. A. Srinivas Rao, Principal, Bhaskar Pharmacy College, Moinabad for his continuous support.
CONFLICTS OF INTEREST: There is no conflict of interest from all the authors.

\section{REFERENCES:}

1. Smolders EJ, Jansen AME, Horst PGJ, Rockstroh J, Back DJ and Burger DM: Viral Hepatitis C Therapy: Pharmacokinetic and Pharmacodynamic Considerations: A 2019 Update. Clin Pharmacokinet 2019; 58(10): 1237-63.

2. Drugbank: https://www.drugbank.ca/drugs/DB08934

3. Bhatia HK, Singh H, Grewal N and Natt NK: Sofosbuvir: A novel treatment option for chronic hepatitis $\mathrm{C}$ infection. Journal of Pharmacology \& Pharmacotherapeutics 2014; 5(4): 278-84.

4. Bonaventura A and Montecucco F: Sofosbuvir/velpatasvir: A promising combination. World J Hepatol 2016; 8(19): 785-89.

5. Drugbank: https://www.drugbank.ca/drugs/DB11613

6. Somia G and Asra H: Development and validation of UVspectrophotometric method for estimation of velpatasvir in bulk form by absorbance maxima method. Int $\mathrm{J}$ Pharm 2018; 8(2): 28-33.

7. Singh K, Bhatt $S$ and Prasad R: HPLC method for estimation of drug release of Sofosbuvir in pharmaceutical formulation. Int J Pharm Sci \& Res 2019; 10(1): 367-72.

8. Hassona M and Mohamed M: UV-Spectrophotometric and stability indicating RP-HPLC methods for the determination of the hepatitis $\mathrm{C}$ virus inhibitor sofosbuvir in tablet dosage form. Analytical Chemistry Letters 2018; 8(3): 268-76.

9. Sridevi M, Rao DTS and Naidu CG: Development and validation of liquid chromatographic method for simultaneous determination of sofosbuvir, velpatasvir and voxilaprevir in fixed tablet dosage form. J Biomed Pharm Sci 2018; 5(5): 351-60.

10. Rezk MR, Monir HH and Marzouk HM: Spectrophotometric assessment of the brand new antiviral combination: Sofosbuvir and velpatasvir in their pure forms and pharmaceutical formulation. Spectrochimica Acta Part A: Molecular and Biomolecular Spectroscopy 2019; 213: 159-66.

11. Saroja J, Lakshmi PVA, Rammohan Y, Divya D and Santhosh Kumar P: Concurrent estimation of sofosbuvir and velpatasvir in raw and tablets using stability indicating RP-HPLC method. Rasayan J Chem, 2018; 11(3): 105866.

12. Jyothi $U$ and Umadevi DP: Analytical method development and validation for the simultaneous estimation of sofosbuvir and velpatasvir drug product by RP-HPLC method. Indo Am J Pharm Res 2017; 7(8): 40109.

13. Harshalatha $\mathrm{P}$, Chandrasekhar $\mathrm{KB}$ and Chandrasekhar MV: A novel stability indicating method development and validation for the simultaneous estimation of Velpatasvir and Sofosbuvir in bulk and its phar-maceutical formulations. Int J Res Pharm Sci 2018; 9(2): 566-71.

14. Blessy M, Patel RD, Prajapati PN and Agrawal YK: Development of forced degradation and stability indicating studies of drugs-A review. J Pharm Anal 2014; 4(3): 15965.

15. Godela R and Bhavani S: A simple reverse phase-highperformance liquid chromatography method development and validation of valsartan in bulk and its tablet dosage form. Asian Journal of Pharmaceutical and Clinical Research 2017; 10(12): 333-37. 
How to cite this article:

Godela R and Sowjanya G: Simultaneous estimation of velpatasvir and sofosbuvir in bulk and combined tablet dosage form by a simple validated stability indicating RP-HPLC method. Int J Pharm Sci \& Res 2020; 11(11): 5669-78. doi: 10.13040/IJPSR.0975-8232.11(11). $5669-78$.

All @ 2013 are reserved by the International Journal of Pharmaceutical Sciences and Research. This Journal licensed under a Creative Commons Attribution-NonCommercial-ShareAlike 3.0 Unported License.

This article can be downloaded to Android OS based mobile. Scan QR Code using Code/Bar Scanner from your mobile. (Scanners are available on Google Playstore) 